\title{
Review
}

\section{Mediterranean-climate oak savannas: the interplay between abiotic environment and species interactions}

\author{
Teodoro Marañón, Francisco I. Pugnaire and Ragan M. Callaway
}

\begin{abstract}
Marañón, T., Pugnaire, F. I. and Callaway, R. M. 2009. Mediterranean-climate oak savannas: the interplay between abiotic environment and species interactions. - Web Ecol. 9: 30-43.
\end{abstract}

\begin{abstract}
Mediterranean oak savannas cover about 4 million ha in California (northwest America) and 3 million ha in Spain and Portugal (southwest Europe), and are ecologically and socio-economically important systems. Here we review literature on the interactions between the two dominant elements of savannas - the oak overstorey, the herbaceous understorey, and the surrounding grassland matrix. We focus on the main ecological factors affecting the oak understorey environment: shade, soil moisture, soil nutrients, and animal-mediated effects. We then review the main features of the herbaceous community in the oak understorey, as compared to the adjacent open grassland, in terms of species composition, biomass, diversity, and soil seed bank. We examine processes associated with oak regeneration and growth, and their relationships with the herbaceous layer and other woody plants cover. Finally, we discuss the complex facilitative and interference interactions that occur in oak-grassland systems and review models proposed to explain the dynamics and coexistence of oak trees and herbaceous plants in savannas.
\end{abstract}

T. Marañón (teodoro@irnase.csic.es), IRNASE, CSIC, PO Box 1052, ES-41080 Sevilla, Spain. - F. I. Pugnaire, Estación Experimental de Zonas Aridas, CSIC, General Segura 1, ES-04001 Almeria, Spain. - R. M. Callaway, Division of Biological Sciences, Univ. of Montana, Missoula, MT 59812, USA.

Mediterranean savannas are landscapes with a continuous herbaceous cover and scattered trees. Savannas are usually intermingled with patches of woodland, shrub-land, treeless grasslands, and crop-lands forming a complex mosaic. Heterogeneity in topography, soil and climate, interactions among species, and the superimposed selective activity of wild and domestic herbivores, in addition to human activities such as clearing, ploughing and burning are main agents forging this type of landscape.

Oaks are the dominant trees in the wooded pastures (called dehesas or montados) of the Iberian Peninsula (west Mediterranean Basin) and in the savannas of California (northwest America). However trees and shrubs belonging to many taxonomic groups may form savannalike systems in other regions with Mediterranean climate. These include Juniperus sp. and Retama sphaerocarpa in Spain, Pistacia atlantica and Ceratonia siliqua in north Africa, Acacia caven in Chile, other Acacia species in central Africa, Protea nitida in south Africa and Eucalyptus sp. in Australia.

Interactions between the two contrasting life-forms, trees and herbs, in savannas may be synergistic or antago- 
nistic, and may reflect stochastic variation or positive feedbacks (Scholes and Archer 1997). Overstorey trees compete with the understorey plants for resources, but they also provide benefits for them, such as shade, higher nutrient levels, more available moisture, protection from herbivores, more favourable soil micro-flora, and shared resources via mycorrhizae (Callaway and Pugnaire 2007). This combination of positive and negative effects of oaks on herbaceous species often result in understorey communities very different from the surrounding open grass-land (Callaway et al. 1991, Rice and Nagy 2000, Ludwig et al. 2004).

Perceptions of the role of trees in mixed tree-herb systems has historically differed between the Iberian Peninsula and California, although there has been a recent convergence. In the old, traditional management of Iberian dehesas there was a perception of oaks as benefactors because of their acorn production and shelter for domestic animals (Parsons 1962). More recently, the ecological benefits of tree persistence for the system sustainability and to maintain biodiversity has been documented and promoted in Spain and Portugal (González-Bernáldez et al. 1969, Marañón 1988, Joffre et al. 1988, 1999, Pulido et al. 2001, Pereira and da Fonseca 2003, Eichorn et al. 2006). Before European settlement in California, native inhabitants gathered acorns and probably set fires to hunt, both of which were likely to have impact on oak populations. By the 1950's, however, oak trees were mechanically and chemically removed to increase forage production for cattle (Leonard 1956). More detailed ecological effects were studied in the 1960-1980s (Murphy and Crampton 1964, Murphy and Berry 1973, Holland 1980, Parker and Muller 1982, Kay 1987, McClaran and Bartolome 1989) and the facilitative (beneficial) effects of blue oak (Q. douglasii) trees on herbaceous populations were explicitly demonstrated (Callaway et al. 1991). An integrated hardwood rangeland management plan (IHRM) was designed in the 1980s to make oak regeneration and persistence compatible with livestock grazing on oak woodlands (Greenwood 1991, Pavlik et al. 1992).

In this paper, we review the interactions between the two plant elements of the savanna system: the oak tree overstorey and the herbaceous community. First, we introduce the historical and ecological scenarios of the Iberian dehesa (for simplicity we use this term to include also montados in Portugal) and the Californian savanna. Second, we focus on the main ecological factors affecting the oak sub-canopy environment: shade, soil moisture, soil nutrients and animal-mediated effects. Third, we review the main features of the herbaceous community in the oak understorey, compared to the adjacent open grassland, in terms of species composition, biomass, diversity and soil seed bank. We then look at oak regeneration and growth, examining possible influences of the herbaceous layer and also of shrub and tree canopy cover. We further discuss the interactions between facilitation and interference processes in the oak-herb system. Finally, we give an overview of models proposed to explain the dynamics and coexistence of oak trees and herbaceous plants in savannas.

\section{Two contrasted historical and ecological scenarios}

\section{The Iberian dehesa}

Historical human occupation and land use has replaced the once dominant closed forest and shrub-lands in the Mediterranean Basin with open grass-lands and crop-lands. The subsequent extensive disturbance associated with grazing led to the expansion and diversification of early successional species, already existing in naturally disturbed areas. On the other hand, successive westward migrations of mostly Irano-Turanian, steppic species in many cases accompanying the movement of human populations and livestock, brought new herbaceous species. The result of the combined processes of evolution and migration is the rich and heterogeneous assemblage of herbaceous species currently found in the dehesas (Le Houérou 1981, Marañón 1986).

Savanna landscapes in Europe can be traced back to the Pleistocene, resulting from the combined action of ecological factors and human uses of land (Rackham 1998). The extermination of large herbivores (such as elephants), expansion of domestic livestock, alteration of fire regimes, added to wood-cutting and recent forestry practices have affected the transition between forest (being reduced) and savanna (being expanded) in prehistoric and historical times. Oak savannas are old cultural landscapes in Spain and Portugal, already mentioned in the historical travel writings of King Alfonso XI (ca 1350) and Fernando Colón (ca 1510, see references in Rackham 1998). These Iberian oak savannas have much expanded and developed from the 18 th century onwards, currently occupying about 3 million ha (Eichhorn et al. 2006).

\section{The Californian oak savanna}

The Californian oak savanna is formed by sparse evergreen and deciduous oaks within a grassland matrix dominated by introduced annuals. This landscape occupies about 4 million ha on shallow soils, mainly on low elevation slopes surrounding the Central Valley. Northwards (above $42^{\circ}$ latitude) it is replaced by conifer forests under moister and cooler conditions, while southwards (below $33^{\circ}$ latitude) it is replaced by chaparral and more xeric types of vegetation (Allen-Díaz et al. 2007).

Savannas and grasslands became increasingly extensive with the progressive reduction in rainfall (in particular during summer months) that began in the Miocene and persisted until the end of the Tertiary. Pleistocene climatic 
fluctuations were probably responsible for increasing the prominence of the Arcto-Tertiary Geoflora; from this origin would stem the bunchgrasses which dominated the primeval California prairie (Baker 1989).

During pre-European time, native Californians used fire to open woodlands, facilitate acorn harvest, promote forage growth and deer hunt, but their role shaping the present savanna landscape is not clear. Early European ranchers, coming from Mexico about 250 years ago, brought seeds of Euro-Mediterranean weeds, probably mixed with hay and grain, and initiated a large-scale replacement of the native grassland (Baker 1989). A few annual species, such as Avena fatua, A. barbata, Bromus diandrus, B. hordeaceus, Lolium multiflorum, Erodium spp., Hypochoeris glabra and Medicago polymorpha, probably pre-adapted to a high disturbance regime by soil ploughing and cattle grazing and trampling, were highly successful in invading the expanding human-disturbed landscapes of California. In contrast, once dominant bunchgrasses, such as Nassella pulchra, which has not been exposed for millennia to large herbivores and is sensitive to heavy grazing, is now restricted to serpentine soils and other unusual substrates (Bartolome et al. 2007).

\section{Oak understorey environment}

Isolated oak trees in the savanna create distinct micro-environments which may positively or negatively affect the herbaceous community living underneath. In an early study of oak canopy effects in Spanish dehesas, González-Bernáldez et al. (1969) listed eight factors affecting the herbaceous community: interception of radiation, rainfall, and wind, root competition, organic substances in root and litter, litter humification and mineralization, cation mobilization from deep soil layers, and attraction of animals, which accumulate products from other parts of the ecosystem.

The positive effects of nurse plants and shelter-woods facilitating seedling establishment and growth have been widely documented, but it is difficult to separate the effects of temperature, light, moisture and nutrients. There is experimental evidence showing different responses of planted seedlings beneath and away from the tree canopies (Man and Lieffers 1997). Field experiments of reciprocally transplanted soil blocks (thus including seed banks) between open grassland and oak understorey found differences in germination and seedling establishment for the species composing the community, but it is difficult to take apart the intervening factors (Marañón and Bartolome 1993).

The observed facilitation of trees and shrubs on herbaceous plants has been attributed in most cases to indirect canopy effects such as increased soil moisture (Holmgren et al. 1997), higher nutrient availability (Callaway et al. 1991) and amelioration of temperature extremes (Franco and Nobel 1989). In the following sections we review the main factors characterizing the understorey environment as opposed to the open grassland: shade, soil moisture and nutrients, and animal-mediated effects.

\section{Shade}

Interceptions of sunlight and of long-wave radiation emission from the soil at night are fundamental physical effects of the tree canopy. In savannas, tree canopies may reduce direct and indirect sun radiation reaching the understorey by $25-90 \%$ (Belsky et al. 1989, Georgiadis 1989, Jackson et al. 1990, Callaway et al. 1991, Ko and Reich 1993). A model to optimize Quercus ilex density for silvopastoral use in the Iberian dehesas estimated that radiation available for pasture decreased up to $21 \%$ with a density of 24 oaks $\mathrm{ha}^{-1}$ and $13 \%$ canopy cover (Montero et al. 2008). In spite of this light reduction, understorey plants appear to have enough radiation to sustain a relatively high rate of photosynthesis (Mordelet and Menaut 1995, Moreno et al. 2007). On the other hand, annual plants benefit from the winter-deciduous habit of oaks in California (such as $Q$. lobata and $Q$. douglasii) which are leaf-less during most of these plants' growing season.

Shade has other effects, such as buffering soil temperature extremes, which affects seed germination and seedling establishment. Ameliorating temperature extremes also reduces water loss and reduces photo-inhibition during stomatal closure, but at the cost of reducing energy for photosynthesis (Callaway and Pugnaire 2007). However, transpiration and leaf temperatures may remain high in the understorey because of the heated air and energy advected from the surroundings (Scholes and Archer 1997). Shade tolerance is produced by complex mechanisms which depend on the efficiency of carbon gain in low light and on the resistance to biotic and abiotic stresses in the understorey environment (reviewed by Valladares and $\mathrm{Ni}$ inemets 2008).

The sharp reduction in light caused by the dense canopy of evergreen oak ( $Q$. agrifolia) precluded seedling establishment of most grassland species in soil blocks transplanted to the understorey (Marañón and Bartolome 1993). Shade-tolerant species, such as Montia perfoliata and Stellaria media, seem to be excluded by competition in open sites, whereas light-demanding species, such as Bromus hordeaceus and Hypochoeris glabra would not survive under closed evergreen oak canopies. A few species, like Bromus diandrus and Carduus pycnocephalus have a wider ecological range and grow in both habitats (Marañón and Bartolome 1993, 1994).

The distributions of the two Bromus congeners, B. diandrus and $B$. hordeaceus, in oak savannas are influenced by a combination of shade and soil nutrients factors as well as interspecific competition. Both species were planted in the open and the understorey of $Q$. douglassi. The low abundance of $B$. hordeaceus under canopies was not simply due to the environment created by the canopy, but because of com- 
petitive exclusion from $B$. diandrus, as shown by a significant decrease in reproductive rate with increasing $B$. diandrus density. Bromus diandrus, on the other hand, did not appear to be significantly influenced by competition from $B$. hordeaceus, suggesting that its close association with oak canopies is due in part to its inability to adapt to lower nutrients in the soils of the open grassland (Rice and Nagy 2000).

In semi-arid eastern Spain, shade effects by the leguminous shrub Retama sphaerocarpa have been documented. Under Retama canopies there is about 60\% less radiation and $7^{\circ} \mathrm{C}$ lower soil temperatures than in the open, resulting in higher environmental heterogeneity which in turn may allow different herbaceous species to coexist (Moro et al. 1997).

\section{Soil moisture}

Water availability is a limiting factor for plant growth during the dry season in Mediterranean-type climates. The pattern of rainfall interception by the tree canopy, flow to the ground, infiltration and storage in soil as well as losses through surface flow and evapo-transpiration will determine the water balance and the type of interaction between the tree and the herbaceous understorey. The tree understorey may receive $5-50 \%$ less rainfall than the overstorey because of rain interception; although stem-flow can concentrate moisture near the trunk base, and the edge drip can also increase the soil moisture at the canopy perimeter (Strang 1969, Stuart-Hill et al. 1987). The proportion of precipitation reaching the ground under the oak tree will depend on the intensity and amount of the rainfall events (Callaway and Nadkarni 1991) and the characteristics of the particular tree: canopy size and architecture, leaf area, and bark texture (Haworth and McPherson 1995). Under isolated oak trees in Spain, Luis et al. (1978) recorded $19-24 \%$ less rainfall than in the open, with northern and eastern aspects (opposite to prevailing moist winds) showing the least throughfall inputs.

The water status of plants in the understorey is the outcome of both positive and negative effects caused by the tree canopy on the soil and air beneath it. The shade of trees lowers the soil temperature, which has several hydrologic consequences: reduced evaporative demand and water stress on understorey plants, enhanced soil moisture storage and availability and higher water-use efficiency (Joffre et al. 1988, Belsky et al. 1989, Ko and Reich 1993, Mordelet and Menaut 1995). Hydraulic lift from deep roots of the oak tree may also increase soil moisture to shallow-rooted understorey herbaceous plants (Dawson 1993).

Canopy throughfall (and litterfall) increase soil nutrients near the trees and may explain the higher understorey grass productivity (Holland 1980, Callaway et al. 1991). In addition, Ishikawa and Bledsoe (2000) observed diurnal fluctuations in water potential in soils under $Q$. douglasii that were indicative of hydraulic lift. The water lifted at night dur- ing the dry summer (estimated amount of 0.25-8.8 1 per day and tree) is redistributed to the upper soil layers and made available to the fine roots of the oak tree as well as for the understorey plants, mycorrhizal fungi and decomposers (Kurz-Besson et al. 2006, Querejeta et al. 2007). This hydraulic lift may play a role in the general facilitative effect of the oak trees, despite the fact that diurnal patterns did occur until later in the summer when the annual grasses had already senesced. Thus, the water released by oak roots could delay the rate of soil water depletion in understorey communities.

On the contrary, there are negative effects of trees on understorey soil moisture. Fine feeder roots of trees can be very efficient at depleting the near-surface soil moisture, while large root channels facilitate the deep percolation and storage of water, only available to the deep-rooted trees. Tree litter accumulated underneath oak canopy can reduce the amount of moisture reaching the mineral soil, hence decreasing water available to herbaceous plants.

At the landscape level, the mixture of oak trees and herbaceous plants influences the pattern of water distribution because a dense grass cover improves infiltration (Joffre and Rambal 1993). When trees depress herbaceous production and cause bare ground patches, water and nutrients can be lost via surface flow (Schnabel 1997).

In dehesas of Spain, Alonso and Puerto (1978) found higher water storage capacity and total soil porosity, associated with higher organic matter, in soils under oak trees than in the open; there was also a higher soil permeability which they attributed to the dense root system of herbaceous plants found underneath. Joffre and Rambal (1988, 1993) measured a significant delay in soil water loss under Quercus rotundifolia and Q. suber relative to soils in the open.

On transects perpendicular to the oak understoreyopen grassland ecotone, Marañón and Bartolome (1994) found that after relatively consistent soil moisture throughout the winter, the water content decreased more rapidly in the open (to $15 \%$ ) than in the understorey (26\%) later in the spring. The longer period of soil moisture availability under the oak canopy allows for a longer growth period and may favour perennial species like Elymus triticoides and Lathyrus vestitus living in that habitat.

Woody plants can also be positively affected by the herbaceous layer in terms of water availability. In semi-arid southeastern Spain, a dense understorey cover of herbs may help to retain rainfall water in the soil accumulated under the shrub Retama sphaerocarpa, improving its water status by lowering evaporation (Pugnaire et al. 1996b, Domingo et al. 1999).

\section{Soil nutrients}

The pattern of nutrient enrichment of soils under tree canopies, forming 'islands of fertility', has been widely 
documented in tropical savannas (Kellman 1979, Virginia 1986, Belsky et al. 1989, Georgiadis 1989, Weltzin and Coughenour 1990, Isichei and Muoghalu 1992, Vetaas 1992, Mordelet et al. 1993, Belsky 1994), as well as in Mediterranean oak savannas of Spain (González-Bernáldez et al. 1969, Alonso and Puerto 1978, Escudero et al. 1985, Joffre et al. 1988, Moreno et al. 2007) and California (Holland 1980, Parker and Muller 1982, Jackson et al. 1990, Callaway et al. 1991, Marañón and Bartolome 1994, Dahlgren et al. 1997). Nutrient enrichment is particularly important for the herbaceous plants since most oak savannas are developed on relatively nutrient-poor soils.

In dehesas of Spain, oak trees increased soil organic matter (2.5-5.6 times) compared to open grassland; these increments were greater on sandy soils (Alonso and Puerto 1978). Isolated oak trees were major sources of temporal and spatial heterogeneity of soil $\mathrm{N}$ : the potential mineralization rate (2.3 times), microbial biomass- $\mathrm{N}$ (1.7 times), and soil mineral $\mathrm{N}$ (1.8 times) were higher under oak canopies than in open grassland (Gallardo et al. 2000). Maximum levels of soil ammonium and nitrate were associated with minimum potential mineralization rate (during autumn and winter), indicating a nutrient accumulation caused by the reduced plant uptake. In general, understorey soil nutrients increase with time and age of the tree (Facelli and Brock 2000). This temporal pattern induced by overstorey age has been shown for soil carbon and nitrogen (Bernhard-Reversat 1982) as well as phosphorus and potassium (Pugnaire et al. 1996b).

Several complementary mechanisms have been proposed to explain the observed soil nutrient enrichment under trees in savannas (Virginia 1986): 1) the trees, acting as nutrient pumps, draw mineral elements from a large soil volume explored by their root systems (from deep horizons and from areas beyond the canopy) and deposit those nutrients on the ground beneath the canopy, via litterfall and canopy leaching (Kellman 1979, Scholes 1990); 2) the tree canopy, a tall and leafy structure with high surface/volume ratio acts as a trap for atmospheric dust and mineral elements contained in it (Pugnaire et al. 1996a, Whitford et al. 1997); 3) rain may wash the mineral elements in the dust covering leaves and twigs to the ground (Bernhard-Reversat 1982, Escudero et al. 1985); 4) tree canopies attract birds and large herbivores, which tend to concentrate nutrients (and also seeds) with their droppings in the understorey (Georgiadis 1989, Belsky 1994, Archer 1995); 5) shrubs and trees that fix nitrogen, such as legumes, contribute to those 'fertility islands' in savannas (Virginia 1986, Vetaas 1992, Facelli and Brock 2000).

\section{Animal-mediated effects}

Trees attract different kinds of animals, from large herbivores to small invertebrates, which direct or indirectly af- fect the herbaceous understorey. Soil may be enriched by faeces dropped by wild and domestic herbivores, seeking the oak shade as protection, and hence favouring nutrientdemanding plants underneath the canopies.

Herbaceous fodder under oak trees in dehesas of Spain was richer in N, P, K, Ca and $\mathrm{Mg}$ than adjacent open grasslands (Montalvo et al. 1980), and similar differences were found for oaks and grasslands in California (Holland and Morton 1980). Oak trees provide the sub-canopy herbaceous community with mineral elements initially sequestered in the oak litter, which is mineralised and taken up by herbaceous plants, thus becoming available for large herbivores attracted by the oak canopy environment. This tree-induced increase in nutritional value of sub-canopy plants may raise them above the critical threshold for digestion by ruminants grazing in the savanna system (Scholes 1990).

Birds perch on the trees and disperse seeds underneath, increasing the abundance of bird-dispersed plants in the understorey and contributing to regeneration nuclei in the system (Galindo-González et al. 2000, Manning et al. 2006). On the contrary, trees may attract small mammals, birds and insects, which will predate on seeds and seedlings of the trees and also of the herbaceous plants in the understorey. For example, the preferred habitat of the invader Hypericum perforatum in shaded areas of California savannas has been interpreted as a consequence of the breeding behaviour of the beetle Chrysolina quadrigemina (introduced as pest control) that prefers unshaded sites for egg-laying (Harper 1977).

At the landscape level, grazing reduces fuel load of the herbaceous layer, hence diminishing the risk of fire and tree mortality; however, a heavy grazing pressure may suppress tree regeneration. The interaction of grazer-browserfire strongly influences the tree-grass dynamics (Scholes and Archer 1997, Higgins et al. 2000).

Tree canopies in savannas are usually kept above the browsing line by large herbivores, which also feed on the herbaceous understorey. However, in the Mediterranean landscape there are often closed clumps of tough, thorny or spiny shrubs such as Pistacia lentiscus, Olea europaea, Crataegus monogyna, Maytenus senegalensis and Zyzyphus lotus, inside of which herbaceous plants may find refuge from large herbivores. In the overgrazed Mediterranean systems, protection from grazing and browsing may be the main cause of facilitation and survival of many palatable plants, more importantly than other positive effects (Callaway et al. 2000).

\section{Herbaceous communities}

Isolated oak trees in savannas affect species composition, diversity and biomass of the herbaceous communities underneath, in comparison with those in the open, betweentree spaces. The growth pattern of individual herbaceous 
plants under the oak canopy is determined by requirements for light, water, and nutrients, which are modified in this microhabitat, and conditioned also by interference with other plant species, by their resistance to litter accumulation, and by disturbance caused by animals.

In the following sections we review the main changes in species composition, biomass, diversity, and soil seed banks of understorey herbaceous communities compared to open grasslands.

\section{Species composition}

There can be strong effects of oak canopies on the growth and reproduction of herbaceous plants beneath, often inducing a species replacement and consequent change in the herbaceous community. The spatial distribution of species shows a gradual change from the oak trunk to the canopy edge (drip line) and into the open, inter-tree gaps (Marañón 1986, Marañón and Bartolome 1994, Scholes and Archer 1997). Marañón (1986) detected a main trend of floristic variation associated with oak canopies in southwest Spain dehesas, that was consistent over a wide range of sites ( 40 sites with $\mathrm{pH}$ values from 4.8 to 7.5 ). 'Canopy-seeker' species like Hordeum murinum, Urospermum pycroides, Cynosurus echinatus and Dactylis glomerata were abundant in the oak understorey while other species were mostly found away from the canopy. Other studies have also documented changes of species composition in herbaceous communities under oak trees, in comparison with adjacent open grasslands, in dehesas of Spain (GonzálezBernáldez et al. 1969, Puerto et al. 1980), and in savannas of California (Holland 1980, Parker and Muller 1982, McClaran and Bartolome 1989, Callaway et al. 1991, Marañón and Bartolome 1994).

Facilitation seems to favour perennial grasses such as Dactylis glomerata, Lolium perenne and Festuca ampla in the oak understorey in Spanish dehesas (Puerto et al. 1980, Marañón 1985a, 1986) and Elymus triticoides in Californian woodlands (Marañón and Bartolome 1994). On the contrary, herbaceous species of lower stature and high light demand, such as Trifolium arvense and Logfia minima tend to avoid the oak understorey; they are excluded by the tree, directly through shade and litter accumulation, and indirectly by competitive displacement from tree canopyfavoured species (Marañón 1986). A reverse situation is illustrated in California by some herbaceous species, such as the native Montia perfoliata, which find refuge under the oak canopy from intense competition by more aggressive, annual invaders that dominate the open grassland (Marañón and Bartolome 1993).

Differences in species composition between the understorey and the open tend to be accentuated in drier climates, because the environmental gradient is stronger and so is facilitation, as evidenced from Californian savannas (McClaran and Bartolome 1989) and tropical savannas (Belsky et al. 1993a). Heavy grazing can, on the other hand, homogenise the spatial patterning of herbaceous communities, by suppressing shade-dominant plants and favouring overall grazing-resistant species (Belsky et al. 1993b).

\section{Biomass}

There are no clear patterns of grassland productivity beneath oak trees. Productivity under oak canopies can be higher (Holland 1980, Callaway et al. 1991, Moreno 2008), lower (Parker and Muller 1982, McClaran and Bartolome 1989, Marañón and Bartolome 1994), or not significantly different (Jackson et al. 1990) from open grassland. These inconsistencies may be explained by environmental factors and specific growth forms in the understorey (McPherson 1992).

Plant growth under $Q$. agrifolia canopies was slower than in the open but the growth period under the canopy extended much farther into the dry season (Marañón and Bartolome 1994). Managers of Spanish dehesas value the oak sub-canopy grassland (about $10-30 \%$ of total grassland area) because it provides forage early in the autumn and winter (as perennial grasses resprout quickly after the first autumn rains), and also in late season (as senescence delays). This adds to the value of acorns and browsing of the oak itself (Joffre et al. 1988).

Rainfall gradients affected herbaceous production in Californian $Q$. douglasii savannas. It was proportionally higher under tree canopies relative to that in gaps, in dry climates, but proportionally lower where annual rainfall was above $500 \mathrm{~mm}$ (McClaran and Bartolome 1989, Ratliff et al. 1991). This changing pattern was explained as facilitation by amelioration of environmental conditions, the alteration of substrate characteristics, and increased resource availability in the understorey (Callaway 1995, 2007). However Moreno (2008) found that the positive effect of oak trees on pasture yield was more prominent on the wettest sites (yield increased 33\% for $661 \mathrm{~mm}$ rainfall versus $17 \%$ for $452 \mathrm{~mm}$ ), and suggested that competition for water could counterbalance beneficial shade and fertility effects in semi-arid dehesas. In other cases (such as in African savannas) there were no significant effects of rainfall variation on grassland productivity under tree canopies (Mordelet and Menaut 1995).

Facilitation may be more important than competition when trees are young, increasing grass production underneath; however, as trees and shrubs grow larger, competition may overshadow facilitation and reduce herbaceous production in tropical savannas (Archer 1995, Scholes and Archer 1997). In contrast, in Californian savannas older and larger Q. douglasii appear to have stronger facilitative effects than smaller trees (Callaway et al. 1991). At the landscape level, total herbaceous production may increase from the tree-less grassland to savannas, but decrease as tree density increases in woodlands (Scholes and Archer 1997). 
The whole ecosystem productivity, i.e. oaks (browse and acorns) plus herbaceous layer productivity, should be considered by savanna managers (Joffre et al. 1988, Jackson et al. 1990).

On the other direction of the tree-grass interaction, the grassland layer may have contrasting effects on tree growth, depending on soil type and water balance. Removal of grass increased production of Acacia tortilis trees in a nutrientrich savanna with fertile, fine-textured soil, but did not affect growth of Burkea africana trees in adjacent nutrientpoor savanna woodland with coarse-textured soil (Knoop and Walker 1985). Tree roots are able to use water from deeper layers in coarse-textured soils (being independent from grasses), while grasses limit the water recharge on the fine-textured soils and hence reduce tree growth. The outcome of these interactions is regulated by further interactions between rainfall amount and seasonality, and soil texture and grass cover (Scholes and Archer 1997).

\section{Diversity}

Grazed oak savannas in the Mediterranean Basin are extraordinarily rich in plants species, showing the highest diversity records (among temperate and Mediterranean vegetation) at the 0.1 ha plot scale: 179 species in an open Pistacia lentiscus shrubland in Israel (Naveh and Whittaker 1979), and 135 species in a Quercus ilex subsp. ballota dehesa in south Spain (Marañón 1985a).

Several ecological and evolutionary factors appear to promote high species richness in the Mediterranean $\mathrm{Ba}$ sin grasslands (Naveh and Whittaker 1979). 1) due to its transitional biogeographical location, the Mediterranean Basin has received floristic elements from neighbouring Euro-Siberian, Irano-Turanian and (to a lesser extent) Saharo-Arabian regions, added to the own Mediterranean derivatives; 2) the complexity of the mountain relief originates isolation and speciation processes; and 3) the long history of intense human impact has promoted species diversification (mainly of annual plants) in a variety of forms adapted to drought, fire and grazing. In this ecologically rich scenario, the isolated oak trees of the savannas represent a source of environmental heterogeneity that increases landscape diversity (Marañón 1986).

At a reduced spatial scale, and focusing on the herbaceous community under the oak canopy, the species richness there is lower than in the open grassland. For example, in a comparative study of 41 oak trees in a wide geographical range of south Spain, average species richness under oak trees was $41 \%$ lower than in the open grassland (Marañón 1986). In California, the herbaceous community under Quercus agrifolia had about 40\% lower species richness than in the open (Marañón and Bartolome 1994). Several factors have been suggested to explain this pattern. Some of them imply direct interference processes, such as the lower light reaching the soil, allowing less 'packed' spe- cies underneath, or physical and allelopathic impact of oak litter. Interference can be also mediated by animals overusing tree shade and trampling underneath. On the other hand, facilitation processes associated with soil enrichment and improved water conditions may favour competitive dominance by few perennial grasses which displaces other plants and reduces community diversity (Rice and Nagy 2000). Other arguments are more subtle, acting at the community-level, like the canopy-induced homeostatic effect on micro-climate variability, which would reduce the ranges of the available regeneration niches and therefore herbaceous diversity (Marañón and Bartolome 1989). Species-poor understorey communities might also indicate that comparatively fewer shade-tolerant herbaceous species have evolved in Mediterranean climates.

Lower species richness under oak trees, however, does not mean a diversity loss at the landscape level because there is a species replacement between the oak understorey and the open grassland, as discussed above. The average species turnover, or beta diversity, between the two microhabitats was calculated as 1.8 for southwest Spain dehesas (Marañón 1986). Moreover, the canopy edge or drip line represents an ecotone between two micro-habitats and frequently shows a species diversity peak (González-Bernáldez et al. 1969, Marañón 1986).

At the landscape level, there is a combination of facilitation and interference processes. Oak trees facilitate growth and reproduction of 'canopy-seeker' species, which barely survive in the open grassland. At the same time, oak trees interfere and displace 'canopy-avoider' species, only found in the open conditions; these herbaceous species would eventually disappear from a closed forest. There are also some generalist species sharing both habitats. The net outcome is a savanna landscape of high diversity, partly due to the micro-habitat heterogeneity and facilitation effects associated with the oak trees (Puerto et al. 1980, Marañón 1986). The species specifically related to the oak canopy may represent about $40-60 \%$ of the total landscape species richness in Mediterranean savannas (Marañón 1985a, 1986, Marañón and Bartolome 1994).

Scattered trees in savannas are keystone structures because they have important ecological functions, and provide unique habitats (within the grassland matrix) for a variety of animals, plants and micro-organisms, thus enhancing the biodiversity of the system (Manning et al. 2006).

\section{Soil seed bank}

Oak trees can affect the demographic fate of herbaceous plants underneath and thus determine community structure and composition. The soil seed reserve and the patterns of seedling emergence are key stages in the annualdominated communities (Bartolome 1979). Species composition and abundance, at the seedling stage, depends on 
the dormancy of the seeds and environmental conditions during emergence and establishment.

In general, there are fewer seeds in forest soils than in open grassland soils (Thompson 1987). In a dehesa of southwest Spain, the estimated seed bank was much higher in the open grassland soil (about 50000 seeds $\mathrm{m}^{-2}$ ) than under the oak canopy (31000 seeds $\mathrm{m}^{-2}$ ). Seedling emergence was also lower (2.8 times) in the oak understorey (Marañón 1985b).

In California, the estimated soil seed bank was 41000 seeds $\mathrm{m}^{-2}$ in open grassland, but only 7000 seeds $\mathrm{m}^{-2}$ in adjacent Quercus agrifolia woodland (Marañón and Bartolome 1989). Seedling emergence represented $30 \%$ of the seed reserve in both habitats, but varied greatly between species, e.g. from $81 \%$ (Montia perfoliata) to $7 \%$ (Stellaria media) in the understorey, and from 52\% (Hypochoeris glabra) to $1 \%$ (Silene gallica) in the open grassland. Species with high seed bank and low seedling emergence (such as Stellaria media and Silene gallica) seem to have a disturbance-adapted, persistent seed bank. In general, species composition and relative abundance of seedlings reflected what was in the soil seed bank, probably because many annual species have a transitory seed bank. Seeds in the soil bank are ready to germinate and emerge with the early autumn rains. Some exceptions are the small-seeded species like Stellaria and Silene, and the hard-seeded legumes, such as Trifolium spp. and Medicago polymorpha (Bartolome 1979, Marañón and Bartolome 1989).

The average seed mass, at the community level, tends to be higher under shaded conditions in forest habitats (Baker 1972). Shade and low radiation would be a selective pressure towards larger investment in nutritional seed reserves, producing larger and more vigorous seedlings able to overcome the limited light resource.

The broad spectrum of regeneration requirements (seed production, seed bank, safe sites, seed dormancy and seedling emergence) favours the coexistence of species with different regeneration niches in the herbaceous community (Marañón and Bartolome 1989, Moro et al. 1997). The unpredictable pattern of rainfall during the growing season in the Mediterranean climate, in particular during the early autumn, may allow coexistence of species that differ in their regeneration niches (Peco and Espigares 1994). However, in the oak understorey habitat, environmental fluctuations are buffered by tree canopies reducing the spectrum of regeneration syndromes and hence species diversity (Marañón and Bartolome 1989).

\section{Oak regeneration}

Oak trees have dominant effects on micro-environments, and hence on the herbaceous community underneath (as discussed in detail above), however, the herbaceous plants may affect tree demography, particularly at the juvenile stage. Woody plant recruitment may be regulated by the herbaceous community, either directly through competition for light, water, and nutrients, or indirectly by grassinduced fire frequency and intensity (Scholes and Archer 1997). Grass biomass influences the fire regime and may suppress tree sapling growth in savannas. Frequently, dwarf trees with well-developed root systems are mixed with the grasses until a drought event or increased grazing pressure reduce grass growth. At that moment trees grow and escape from the grass layer achieving vertical dominance (Scholes and Archer 1997).

Shade from shrubs can also positively affect oak regeneration. In an experiment planting oak seeds in different micro-habitats, Callaway (1992) found that all unshaded, caged, oak seedlings in a grassland died, whereas 35\% of the shaded and caged seedlings survived for at least one year. In southern France, germination of Quercus humilis acorns improved under shrubs (Buxus sempervirens and Juniperus communis), and significantly more seedlings occurred under the shrubs than in the open (Rousset and Lepart 2000).

The canopy cover of trees and shrubs is a main factor influencing oak regeneration. Seedling survival of $Q$. ilex seedlings decreased linearly with light availability in southern Spain (Gómez-Aparicio et al. 2008). In more exposed sites, the combination of high radiation and summer drought negatively affected seedling water status, aggravated with photoinhibition and overheating. In a parallel experiment seedling survival of deciduous $Q$. canariensis was also negatively affected by light, whereas evergreen $Q$. suber did not show a significant effect. Instead, time of emergence (in turn affected by local winter water-logging) was the main predictor of cork oak seedling survival (Urbieta et al. 2008).

There are structural and physiological evidence to support that shade alleviate drought stress for oak seedlings. Under drought conditions, seedlings subjected to artificial shade treatment had higher specific leaf area, higher photosynthetic rate, stomatal conductance, and $\mathrm{N}$-concentration than seedlings under full light (Quero et al. 2006). In contrast, other experiments demonstrated that oak seedlings in the shade were less efficient in osmotic adjustment and effective control of water loss (Aranda et al. 2005). Under natural conditions, the tolerance to simultaneous, multiple stresses, and the interaction with herbivores, pathogens and other plants will determine the outcome of oak seedlings.

Nurse plants may have a very important role in protecting oak seedlings from herbivores. Callaway (1992) found that acorns of the Californian oak Quercus douglasii were more intensely predated on by rodents under shrubs, while emergent seedlings were eaten preferably by deer in the open grassland. The most favourable outcome of these two main predation risks is that acorns surviving early rodent predation under shrubs become seedlings, and occupy sites relatively free from deer grazing. Not all shrubs have the same efficiency as nurse plants; in fact there is a 
non-random distribution of oak seedlings associated with different shrub species in the Californian savannas. After experimental manipulations, Callaway and D'Antonio (1991) found that $43 \%$ of the germinating seedlings survived under Ericameria ericoides and 34\% under Artemisia californica, while there was no survival under Lupinus chamissonis. Species specificity in the facilitation effects of nurse shrubs suggest that, besides the modification of the micro-climatic conditions, there are particular traits in shrubs that favour oak seedling establishment (Callaway 1998). For example, the possession of spines, tough tissues and chemical defences can allow shrubs to provide protection against herbivores. Moreover, rather than direct protection by spines or toxic compounds, plants may also indirectly benefit from being within a complex community where foraging efficiency by herbivores is reduced (Callaway and Pugnaire 2007).

A high proportion of the fallen acorns are harvested and predated upon. In a mixed oak woodland of southern Spain, the probability of oak seed removal was higher under denser plant cover (almost 100\% in a few days) than in the open, which was attributed to the action of small rodents that are more active in shrubby sites where they are protected against predators (Pérez-Ramos et al. 2008). However, a small fraction of the removed and buried seeds can survive and they are crucial for the long term viability of oak populations. In the open oak savannas, the role of mice transporting acorns to the few shrubby sites can allow for some oak seedlings to escape from the intense grazing pressure in the pasture (Pulido and Díaz 2005). At the landscape scale, recruitment of Quercus agrifolia was higher in shrub-dominated patches in central California (Callaway and Davis 1998): e.g. $61 \%$ of the recruits were found in coastal sage scrub, which occupied only $35 \%$ of the landscape.

In some cases, there are stronger negative effects, superimposed by the positive nurse effects of trees and shrubs, and the net outcome is the inhibition of seedling establishment in the understorey. This may be the case for the creosote bush in the Sonoran Desert, where allelopathic compounds produced by their roots may inhibit growth of other plants, thus impeding its function as a nurse plant (Mahall and Callaway 1992). In the case of the evergreen tree Phillyrea latifolia a lower seedling survival (only 10\%) was found under conspecific adults, compared with those under shrubs (41\% under Rosmarinus officinalis and 22\% under Pistacia lentiscus). The depression in seedling emergence and survival under plants of the same species could partly be caused by intra-specific inhibitors in the leaf litter (Herrera et al. 1994).

\section{Balance between facilitation and interference}

A system of oak trees and herbaceous plants forms a mosaic with different intensities of competition and facilitation.
In general, the type of plant-plant interactions in savannas may change in time and space, due to climatic fluctuations, fire incidence or herbivore impact. In consequence a net facilitative effect will be appreciated some years and a net competitive effect in other years (Knoop and Walker 1985, Vetaas 1992, Greenlee and Callaway 1996, Scholes and Archer 1997).

Facilitative mechanisms of shade and nutrient inputs have the potential to facilitate understorey species, but their effects can be outweighed by root interference (Callaway and Pugnaire 2007, Moreno 2008). In Californian savannas, Callaway et al. (1991) demonstrated in bioassays that soil enrichment and litter of Quercus douglasii had strong facilitative effects on the growth of the annual grass Bromus diandrus. However, in field experiments, individual trees with high fine root biomass in the upper soil layers had strong negative effects on the understorey productivity. Negative effects were cancelled in the field in experiments with root exclosures, demonstrating that the interference by oak roots by these particular trees outweighed the positive effects of nutrient addition. In contrast, other $Q$. douglasii trees rooted into the water table and with much lower amounts of fine roots in the upper horizons (trees with much higher water potential) had strong positive effects on the growth of herbaceous plants, and these effects were not affected by root exclosures.

Benefactor species, such as oak in savannas, may have facilitative effects on some herbaceous species (shadetolerant or nutrient-demanding), but competitive effects on other species (light-demanding or tolerant to nutrientpoor soils). The result is a replacement of species in the understorey community, compared to the open grassland, as we discussed previously.

The importance of facilitation over competition tends to increase in conditions of higher abiotic stress or increasing consumer pressure (Bertness and Callaway 1994, Callaway and Pugnaire 2007, Brooker et al. 2008). According to this 'abiotic stress hypothesis', a shift from net competition to facilitation may be expected in plant communities under harsh environmental conditions, prompted by an increase in facilitation rather than by a decrease in competition; see McClaran and Bartolome (1989) for Californian savannas, and Pugnaire and Luque (2001) for southeast Spanish shrublands.

In some cases, competitive interactions that occur between two species, early in development, may be followed by facilitation once one of the species develops a taller canopy and deep roots, thus establishing niche separation. In semi-arid Spain, young Retama sphaerocarpa shrubs interfere with and displace Artemisia barrelieri during early stages of succession, but in later stages Artemisia plants are preferentially found under large Retama shrubs (Haase et al. 1996).

In the Mediterranean oak savannas, complex combinations of negative and positive interactions, operating simultaneously between the oak trees, shrubs and herba- 
ceous plants, under the influence of animals and micro-organisms, must be considered to understand the function of the whole ecosystem. In particular, a better knowledge of the aboveground and belowground resources and their use by oak trees and herbaceous plants would help to develop better management of this agroforestry system (Moreno et al. 2007).

\section{Savanna dynamics}

The fact that a site persists as a savanna rather than as a forest or woodland may indicate that certain portions of that landscape do not provide appropriate conditions for tree establishment, or that tree recruitment is impeded by grazing or fire (Scholes and Archer 1997, Higgins et al. 2000). There are several models to explain the coexistence of trees and herbaceous plants, and to describe savanna dynamics (Walker et al. 1981, Belsky 1990, Scholes and Archer 1997, Higgins et al. 2000, Sankaran et al. 2004).

Rooting niche separation model. Plants with contrasting life-forms, such as trees and small herbs, use resources differently in space and time. Deep-rooted trees are able to explore deep soil layers and take up deeper water reserves, therefore acquiring a niche that is somewhat separate from that of small herbs, which depend mostly on surface soil moisture (Walker et al. 1981, Knoop and Walker 1985, Moreno et al. 2007). Oak trees in Spanish dehesas have large root systems exploring a huge soil volume (more than $20 \mathrm{~m}$ away from the trunk and $4 \mathrm{~m}$ deep), and in consequence limited competition with shallow-rooted herbaceous plants (Moreno et al. 2007).

In general, plant geographers, based on this 'two-layer hypothesis' (Walter 1971), have suggested that trees would have advantages on soils of low-water holding capacity (rocky or sandy soils) in wet climates, and that grasses would thrive on shallow soils underlain by impervious layers, water-retaining clays, in arid environments. This hypothesis has been formalized in Walker and Noy-Meir (1982) analytical model to demonstrate that rooting niche differentiation may allow the stable coexistence of trees and grasses. However, there is substantial contrary evidence suggesting that this theory is not universally valid. For example, many woody species are shallow-rooted and strongly compete with herbaceous plants for the top-soil moisture (Tolsma et al. 1987, Evans and Ehleringer 1994, Hipondoka et al. 2003). In addition, this hypothesis is focused on adult trees and ignores the smaller root depth of seedlings and saplings, and potential competition with grasses (Sankaran et al. 2004).

Phenological separation model. The phenological separation between trees and herbaceous plants can contribute to their coexistence in savannas. Trees take advantage of stored carbohydrates and nutrients, and their ability to take up water deep in the soil, to have a wider phenological activity and thus exclusive access to resources early and late in the growing season. While herbaceous plants are more dependent of current rainfall and temperature regimes. The continuous growth and overtopping strategy of trees would be favoured in seasonal, predictable, moist environments while the opportunistic strategy of herbaceous plants would be more favourable in the arid, unpredictable environments (Scholes and Archer 1997).

In Mediterranean-climate savannas plants are limited by cold in winter and by drought in summer. The growing season of annual plants peaks during the few months of warm and moist conditions. Oak trees are evergreen and active most of the year, although there are winterdeciduous oaks, like Quercus douglasii in California. Despite evidence indicating niche separation by phenology in savannas, how they contribute to coexistence of the two life forms has not been investigated in detail (Sankaran et al. 2004).

Balanced competition model. This model is alternative to the niche separation model, although equally assuming equilibrium conditions. It proposes that intra-specific or intra-functional type competition is greatest but becomes self-limiting at a biomass insufficient to eliminate the interspecific, poorer competitors (Scholes and Archer 1997). A form of balanced competition is found in savannas where mature trees outcompete herbaceous plants, but these, in turn, are able to outcompete establishing trees. In this case the model predicts two meta-stable states: dense woodland and tree-less grassland.

Tree density will be limited by the competition for water between trees and the needed rooting volumes to meet their water demands. Grasses will persist by using water in the interspaces between trees (Sankaran et al. 2004). This model can be applied to optimize management of oak density, water use and grassland production in agroforestry systems (Joffre et al. 1999, Moreno et al. 2007).

Dis-equilibrium model. Frequent disturbance or environmental change will prevent the competitive exclusion or even reverse the competitive hierarchy. According to this type of models, the interaction of a variety of stresses and disturbances, acting differently on trees and herbs, scattered in time and space will determine the savanna dynamics (Scholes and Archer 1997). Grass-tree coexistence in savannas has been explained through interactions between life history and disturbance, by a non-equilibrium mechanism called 'storage effect' (Higgins et al. 2000). Given the overlapping generations and fluctuating recruitment rates, the reproductive potential is 'stored' between generations (hence the 'storage effect'), and allows the population to recruit strongly when conditions are favourable. In savannas, the variation in rainfall and fire intensity leads to variation in tree seedling establishment and recruitment that, against a background of low levels of adult mortality, 
allows the storage effect to promote coexistence (Higgins et al. 2000).

Rather than in competitive interactions, this type of models focuses on demographic mechanisms limiting tree establishment and persistence. In particular, Iberian dehesas can be viewed as transitional dis-equilibrium systems, in which grazing and other disturbances maintain the open woodland state avoiding the transition to forest.

Facilitation model. In contrast to the processes associated with competition between tree and herbaceous plants and their release for allowing coexistence (such as niche partitioning, variation in the physical environment, frequent disturbances, heterogeneity in the ratio of limiting resources, development of local resource depletion and spatial structures that suggest niche facilitation), the positive interactions may directly promote coexistence and increase community diversity (Michalet et al. 2006, Callaway and Pugnaire 2007).

Callaway and Davis (1998) showed a positive association between Quercus agrifolia recruitment and shrubdominated patches in central California, partly explained by facilitation processes, particularly in habitats with high abiotic stress such as south-facing slopes. This shrubfavoured preferential recruitment of oaks may lead to a conversion of shrubland into woodland, given certain conditions of topography, substrate and disturbance regime (Callaway and Davis 1993). Therefore, facilitation processes play a significant role in the model predicting a shifting mosaic of shrubland, woodland and grassland for Californian landscapes.

Synthesis. Several factors act at different scales influencing species coexistence and diversity (Willis and Whittaker 2002). The climate regulates savanna composition at regional or continental scales. At the landscape scale, there are topographic and geomorphic processes related to rainfall, water re-distribution and availability. At local and patch scales, water distribution and disturbance and fire events affect tree-grass mixtures (Coughenor and Ellis 1993).

Models proposed to explain the coexistence of tree and grasses as well as savanna dynamics, should be integrative and include facilitation and competition interactions, tree population demographic limitations, and climate and disturbance regimes, all of them interacting in complex ways (Sankaran et al. 2004).

Acknowledgments - We thank to Fernando Pulido, Jordi Cortina and James W. Bartolome for their comments on an earlier version of the manuscript. During this review, TM was supported by the Spanish MCI projects Dinamed (CGL2005-5830-C03-01) and Interbos (CGL2008-4503-C03-01), FIP by the Spanish Ministry of Science and Innovation (grants CGL2004-00090 and CGL2007-63718), and RMC by the Andrew W. Mellon Foundation, the National Science Foundation, and the Univ. of Montana Sponsored Research Office to RMC. The support is gratefully acknowledged.

\section{References}

Alonso, H. and Puerto, A. 1978. Efectos del arbolado sobre el suelo en diversas comunidades de pastizal. - Anuario del CEBA Salamanca 5: 263-277.

Allen-Díaz, B. et al. 2007. Oak woodlands and forests. - In: Barbour, M. et al. (eds), Terrestrial vegetation of California (3rd ed.). Univ. of California Press, pp. 313-338.

Aranda, I. et al. 2005. Effects of the interaction between drought and shade on water relations, gas exchange and morphological traits in cork oak (Quercus suber L.) seedlings. - For. Ecol. Manage. 210: 117-129.

Archer, S. 1995. Herbivore mediation of grass-woody plant interactions. - Trop. Grassland 29: 218-235.

Baker, H. G. 1972. Seed weight in relation to environmental conditions in California. - Ecology 53: 997-1010.

Baker, H. G. 1989. Sources of the naturalized grasses and herbs in California grasslands. - In: Huenneke, L. F. and Mooney, H. (eds), Grassland structure and function: California annual grassland. Kluwer, pp. 29-38.

Bartolome, J. W. 1979. Germination and seedling establishment in California annual grassland. - J. Ecol. 67: 273-281.

Bartolome, J. W. et al. 2007. Valley grassland. - In: Barbour, M. et al. (eds), Terrestrial vegetation of California (3rd ed.). Univ. of California Press, pp. 367-393.

Belsky, A. J. 1990. Tree/grass ratios in east African savannas: a comparison of existing models. - J. Biogeogr. 17: 483489.

Belsky, A. J. 1994. Influences of trees on savanna productivity: tests of shade, nutrients, and tree-grass competition. - Ecology 75: 922-932.

Belsky, A. J. et al. 1989. The effects of trees on their physical, chemical, and biological environments in a semi-arid savanna in Kenya. - J. Appl. Ecol. 26: 1005-1024.

Belsky, A. J. et al. 1993a. Comparative effects of isolated trees on their undercanopy environments in high- and low- rainfall savannas. - J. Appl. Ecol. 30: 143-155.

Belsky, A. J. et al. 1993b. Effects of widely spaced trees and livestock grazing on understory environments in tropical savannas. - Agrofor. Syst. 24: 1-20.

Bernhard-Reversat, F. 1982. Biogeochemical cycle of nitrogen in a semi-arid savanna. - Oikos 38: 321-332.

Bertness, M. D. and Callaway, R. M. 1994. Positive interactions in communities. - Trends Ecol. Evol. 9: 191-193.

Brooker, R. W. et al. 2008. Facilitation in plant communities: the past, the present, and the future. - J. Ecol. 96: 18-34.

Callaway, R. M. 1992. Effect of shrubs on recruitment of Quercus douglasii and Quercus lobata in California. - Ecology 73: 2118-2128.

Callaway, R. M. 1995. Positive interactions among plants. - Bot. Rev. 61: 306-349.

Callaway, R. M. 1998. Are positive interactions species-specific? - Oikos 82: 202-207.

Callaway, R. M. 2007. Positive interactions and interdependence in plant communities. - Springer.

Callaway, R. M. and D’Antonio, C. M. 1991. Shrub facilitation of coast live oak establishment in central California. Madroño 38: 158-169.

Callaway, R. M. and Davis, F. W. 1993. Vegetation dynamics, fire, and the physical environment in coastal central California. - Ecology 74: 1567-1578. 
Callaway, R. M. and Davis, F. W. 1998. Recruitment of Quercus agrifolia in central California: the importance of shrubdominated patches. - J. Veg. Sci. 9: 647-656.

Callaway, R. M. and Nadkarni, N. M. 1991. Seasonal patterns of nutrient deposition under Quercus douglasii canopies. Plant Soil 137: 209-222.

Callaway, R. M. and Pugnaire, F. I. 2007. Facilitation in plant communities. - In: Pugnaire, F. I. and Valladares, F. (eds), Handbook of functional plant ecology (2nd ed.). CRC Press, pp. 435-455.

Callaway, R. M. et al. 1991. Facilitation and interference of Quercus douglasii on understory productivity in central California. - Ecology 72: 1484-1499.

Callaway, R. M. et al. 2000. Facilitation by unpalatable weeds may conserve plant diversity in overgrazed meadows in the Caucasus Mountains. - Oikos 89: 275-282.

Coughenour, M. B. and Ellis, J. E. 1993. Landscape and climatic control of woody vegetation in a dry tropical ecosystem: Turkana District, Kenya. - J. Biogeogr. 20: 383-398.

Dahlgren, R. A. et al. 1997. Oak trees and grazing impacts on soil properties and nutrients in a California oak woodland. Biogeochemistry 39: 45-64.

Dawson, T. E. 1993. Hydraulic lift and water use by plants: implications for water balance, performance and plant-plant interactions. - Oecologia 95: 565-574.

Domingo, F. et al. 1999. Evapotranspiration model for semi-arid shrub-lands tested against data from SE Spain. - Agric. For. Meteorol. 95: 67-84.

Eichhorn, M. P. et al. 2006. Silvoarable systems in Europe - past, present and future prospects. - Agrofor. Syst. 67: 29-50.

Escudero, A. et al. 1985. The nutrient cycling in Quercus rotundifolia and Quercus pyrenaica ecosystems ('dehesas') of Spain. - Acta Oecolog./ Oecolog. Plantar. 6: 73-86.

Evans, R. D. and Ehleringer, J. R. 1994. Water and nitrogen dynamics in an arid woodland. - Oecologia 99: 233242.

Facelli, J. M. and Brock, D. J. 2000. Patch dynamics in arid lands: localized effects of Acacia papyrocarpa on soils and vegetation of open woodlands of south Australia. - Ecography 23: 479-491.

Franco, A. C. and Nobel, P. S. 1989. Effect of nurse plants on the microhabitat and growth of cacti. - J. Ecol. 77: 870-886.

Galindo-González, J. et al. 2000. Bat- and bird- generated seed rains at isolated trees in pastures in a tropical rainforest. Conserv. Biol. 14: 1693-1703.

Gallardo, A. et al. 2000. Soil nitrogen heterogeneity in a dehesa ecosystem. - Plant Soil 222: 71-82.

Georgiadis, N. J. 1989. Microhabitat variation in an African savanna: effect of woody cover and herbivores in Kenya. - J. Trop. Ecol. 5: 93-108.

Gómez-Aparicio, L. et al. 2008. Oak seedling survival and growth along resource gradients in Mediterranean forests: implications for regeneration in current and future environmental scenarios. - Oikos 117: 1683-1699.

González-Bernáldez, F. et al. 1969. Influences of Quercus ilex rotundifolia on the herb layer at the El Pardo forest (Madrid). - Bol. Real Soc. Esp. Hist. Nat. (Biol.) 67: 265-284.

Greenlee, J. T. and Callaway, R. M. 1996. Abiotic stress and the importance of interference and facilitation in montane bunchgrass communities in western Montana. - Am. Nat. 148: 386-396.
Greenwood, G. B. 1991. Distinguishing the forest from the trees: synthesizing IHRMP research. - In: Standiford, R. B. (ed.), Proc. Symp. on Oak Woodlands and Hardwood Rangeland Manage., USDA, General Tech. Rep. PSW-126. Berkeley, CA, USA, pp. 290-294.

Haase, P. et al. 1996. Spatial pattern in a two-tiered semi-arid shrubland in southeastern Spain. - J. Veg. Sci. 7: 527-534.

Harper, J. L. 1977. Population biology of plants. - Academic Press.

Haworth, K. and McPherson, G. R. 1995. Effects of Quercus emoryi trees on precipitation distribution and microclimate in a semiarid savanna. - J. Arid Environ. 31: 153-170.

Herrera, C. M. et al. 1994. Recruitment of a mast-fruiting, birddispersed tree: bridging frugivore activity and seedling establishment. - Ecol. Monogr. 64: 315-344.

Higgins, S. I. et al. 2000. Fire, resprouting and variability: a recipe for grass-tree coexistence in savanna. - J. Ecol. 88: 213-229.

Hipondoka, M. H. T. et al. 2003. Vertical distribution of grass and tree roots in arid ecosystems of southern Africa: niche differentiation or competition? - J. Arid Environ. 54: 319325.

Holland, V. L. 1980. Effect of blue oak on rangeland forage production in central California. - In: Plumb, T. R. (ed.), Ecology, management and utilization of California oaks. USDA General Tech. Rep. PSW-44, pp. 314-318.

Holland, V. L. and Morton, J. 1980. Effect of blue oak on nutritional quality of rangeland forage in central California. - In: Plumb, T. R. (ed.), USDA General Tech. Rep., Pacific Southwest Station-44, no. 319, Berkeley, CA, USA, pp. 319-322.

Holmgren, M. et al. 1997. The interplay of facilitation and competition in plant communities. - Ecology 78: 1966-1975.

Isichei, A. O. and Muoghalu, J. I. 1992. The effects of tree canopy cover on soil fertility in a Nigerian savanna. - J. Trop. Ecol. 8: 329-338.

Ishikawa, C. M. and Bledsoe, C. S. 2000. Seasonal and diurnal patterns of soil water potential in the rhizosphere of blue oaks: evidence for hydraulic lift. - Oecologia 125: 459-465.

Jackson, L. E. et al. 1990. Influence of tree canopies on grassland productivity and nitrogen dynamics in deciduous oak savanna. - Agric. Ecosyst. Environ. 32: 89-105.

Joffre, R. and Rambal, S. 1988. Soil water improvement by trees in the rangelands of southern Spain. - Oecolog. Plantar. 9: 405-422.

Joffre, R. and Rambal, S. 1993. How tree cover influences the water balance of Mediterranean rangelands. - Ecology 74: $570-582$.

Joffre, R. et al. 1988. The dehesa: an agrosilvopastoral system of the Mediterranean region with special reference to the Sierra Morena area of Spain. - Agrofor. Syst. 6: 71-96.

Joffre, R. et al. 1999. The dehesa system of southern Spain and Portugal as a natural ecosystem mimic. - Agrofor. Syst. 45: 57-79.

Kay, B. L. 1987. Long-term effects of blue oak removal on forage production, forage quality, soil and oak regeneration. - In: Plumb, T. R. and Pillsbury, N. H. (eds), USDA, General Tech. Rep., PSW-100. Berkeley, CA, USA, pp. 351-357.

Kellman, M. 1979. Soil enrichment by neotropical savanna trees. - J. Ecol. 67: 565-577. 
Knoop, W. T. and Walker, B. H. 1985. Interactions of woody and herbaceous vegetation in southern African savanna. - J. Ecol. 73: 235-253.

Ko, L. J. and Reich, P. B. 1993. Oak tree effects on soil and herbaceous vegetation in savannas and pastures in Wisconsin. - Am. Midl. Nat. 130: 31-42.

Kurz-Besson, C. et al. 2006. Hydraulic lift in cork oak trees in a savannah-type Mediterranean ecosystem and its contribution to the local water balance. - Plant Soil 282: 361-378.

Le Houérou, H. N. 1981. Impact of man and his animals on Mediterranean vegetation. - In: di Castri, D. W. G. R. L. S. (ed.), Mediterranean-type shrublands. Elsevier, pp. 479521.

Leonard, O. A. 1956. Effect on blue oak (Quercus douglasii) of 2, 4-D and 2, 4, 5-T concentrates applied to cut trunks. - J. Range Manage. 9: 15-19.

Ludwig, F. et al. 2004. The influence of savanna trees on nutrient, water and light availability and the understorey vegetation. - Plant Ecol. 170: 93-105.

Luis, E. et al. 1978. Relaciones bioclimáticas de diversos factores ecológicos en la encina (Quercus rotundifolia Lam.). VI Simposio de Bioclimatología. - CEBA Salamanca, pp. 268-287.

Mahall, B. E. and Callaway, R. M. 1992. Root communication mechanisms and intracommunity distributions of two Mojave Desert shrubs. - Ecology 73: 2145-2151.

Man, R. and Lieffers, V. J. 1997. Seasonal photosynthetic responses to light and temperature in white spruce (Picea glauca) seedlings planted under an aspen (Populus tremuloides) canopy and in the open. - Tree Physiol. 17: 437-444.

Manning, A. D. et al. 2006. Scattered trees are keystone structures - implications for conservation. - Biol. Conserv. 132: 311-321.

Marañón, T. 1985a. Diversidad florística y heterogeneidad ambiental en una dehesa de Sierra Morena. - Anal. Edafol. Agrobiol. 44: 1183-1197.

Marañón, T. 1985b. Reserva de semillas en el suelo de una dehesa en Sierra Morena: relación con la vegetación. - Anal. Edafol. Agrobiol. 44: 1805-1816.

Marañón, T. 1986. Plant species richness and canopy effect in the savanna-like 'dehesa' of SW Spain. - Ecol. Medit. 12: 131-141.

Marañón, T. 1988. Agro-sylvo-pastoral systems in the Iberian Peninsula: dehesas and montados. - Rangelands 10: 255258.

Marañón, T. and Bartolome, J. W. 1989. Seed and seedling populations in two contrasted communities: open grassland and oak (Quercus agrifolia) understory in California. - Oecolog. Plantar. 10: 147-158.

Marañón, T. and Bartolome, J. W. 1993. Reciprocal transplants of herbaceous communities between Quercus agrifolia woodland and adjacent grassland. - J. Ecol. 81: 673-683.

Marañón, T. and Bartolome, J. W. 1994. Coast live oak (Quercus agrifolia) effects on grassland biomass and diversity. Madroño 41: 39-52.

McClaran, M. P. and Bartolome, J. W. 1989. Effect of Quercus douglasii (Fagaceae) on herbaceous understory along a rainfall gradient. - Madroño 36: 141-153.

McPherson, G. R. 1992. Comparison of linear and non-linear overstory-understory models for ponderosa pine: a conceptual framework. - For. Ecol. Manage. 55: 31-34.
Michalet, R. et al. 2006. Do biotic interactions shape both sides of the humped-back model of species richness in plant communities? - Ecol. Lett. 9: 767-773.

Montalvo, M. I. et al. 1980. Influencia del arbolado sobre la composición química de la hierba. - Anal. Edafol. Agrobiol. 39: 1287-1306.

Montero, M. J. et al. 2008. Light distribution in scattered-trees open woodlands in western Spain. - Agrofor. Syst. 73: 233 244.

Mordelet, P. et al. 1993. Effects of tree clumps on soil characteristics in a humid savanna of west Africa (Lamto, Cote d'Ivoire). - Plant Soil 153: 103-111.

Mordelet, P. and Menaut, J. C. 1995. Influence of trees on aboveground production dynamics of grasses in a humid savanna. - J. Veg. Sci. 6: 223-228.

Moreno, G. 2008. Response of understorey forage to multiple tree effects in Iberian dehesas. - Agric. Ecosyst. Environ. 123: 239-244.

Moreno, G. et al. 2007. Driving competitive and facilitative interactions in oak dehesas through management practices. Agrofor. Syst. 70: 25-40.

Moro, M. J. et al. 1997. Mechanism of interaction between a leguminous shrub and its understorey in a semi-arid environment. - Ecography 20: 175-184.

Murphy, A. H. and Crampton, B. 1964. Quality and yield of forage as affected by chemical removal of blue oak (Quercus douglasii). - J. Range Manage. 17: 142-144.

Murphy, A. H. and Berry, L. J. 1973. Range pasture benefits through tree removal. - Calif. Agric. 27: 8-10.

Naveh, Z. and Whittaker, R. H. 1979. Structural and floristic diversity of shrublands and woodlands in northern Israel and other Mediterranean areas. - Vegetatio 41: 171-190.

Parker, V. T. and Muller, C. H. 1982. Vegetational and environmental changes beneath isolated live oak trees (Quercus agrifolia) in a California annual grassland. - Am. Midl. Nat. 107: 69-81.

Parsons, J. J. 1962. The acorn-hog economy of the oak woodlands of southwestern Spain. - Geogr. Rev. 52: 211-235.

Pavlik, B. M. et al. 1992. Oaks of California. - Cachuma Press.

Peco, B. and Espigares, T. 1994. Floristic fluctuations in annual pastures: the role of competition at the regeneration stage. J. Veg. Sci. 5: 457-462.

Pereira, P. M. and da Fonseca, M. P. 2003. Nature vs nurture: the making of the montado ecosystem. - Conserv. Ecol. 7: 7.

Pérez-Ramos, I. M. et al. 2008. Seed removal in two coexisting oak species: ecological consequences of seed size, plant cover and seed-drop timing. - Oikos 117: 1386-1396.

Puerto, A. et al. 1980. Efecto del arbolado sobre los estratos inferiores de vegetación, en distintas comunidades de pastizal. - Anal. Edafol. Agrobiol. 34: 1321-1330.

Pugnaire, F. I. et al. 1996a. Facilitation between higher plant species in a semiarid environment. - Ecology 77: 1420-1426.

Pugnaire, F. I. et al. 1996b. Facilitation and succession under the canopy of a leguminous shrub, Retama sphaerocarpa, in a semi-arid environment in south-east Spain. - Oikos 76: 455-464.

Pugnaire, F. I. and Luque, M. T. 2001. Changes in plant interactions along a gradient of environmental stress. - Oikos 93: 42-49.

Pulido, F. J. and Díaz, M. 2005. Regeneration of a Mediterranean oak: a whole-cycle approach. - Écoscience 12: 92-102. 
Pulido, F. J. et al. 2001. Size structure and regeneration of Spanish holm oak Quercus ilex forests and dehesas: effects of agroforestry use on their long-term sustainability. - For. Ecol. Manage. 146: 1-13.

Querejeta, J. I. et al. 2007. Hydraulic lift may buffer rhizosphere hyphae against the negative effects of severe soil drying in a California oak savanna. - Soil Biol. Biochem. 39: 409-417.

Quero, J. L. et al. 2006. Interactions of drought and shade effects on seedlings of four Quercus species: physiological and structural leaf responses. - New Phytol. 170: 819-833.

Rackham, O. 1998. Savanna in Europe. - In: Kirby, K. J. and Watkins, C. (eds), The ecological history of European forests. CAB Int., pp. 1-24.

Ratliff, R. D. et al. 1991. California oak-woodland overstory species affect herbage understory: management implications. J. Range Manage. 44: 306-310.

Rice, K. J. and Nagy, E. S. 2000. Oak canopy effects on the distribution patterns of two annual grasses: the role of competition and soil nutrients. - Am. J. Bot. 87: 1699-1706.

Rousset, O. and Lepart, J. 2000. Positive and negative interactions at different life stages of a colonizing species (Quercus humilis). - J. Ecol. 88: 401-412.

Sankaran, M. et al. 2004. Tree-grass coexistence in savannas revisited - insights from an examination of assumptions and mechanisms invoked in existing models. - Ecol. Lett. 7: 480-490.

Schnabel, S. 1997. Soil erosion and runoff production in a small watershed under silvo-pastoral landuse (dehesas) in Extremadura, Spain. - Geoforma.

Scholes, R. J. 1990. The influence of soil fertility on the ecology of African savannas. - J. Biogeogr. 17: 417-419.

Scholes, R. J. and Archer, S. R. 1997. Tree-grass interactions in savannas. - Annu. Rev. Ecol. Syst. 28: 517-544.

Strang, R. M. 1969. Soil moisture relations under grassland and under woodland in the Rhodesian highveld. - Com. For. Rev. 48: 26-40.
Stuart-Hill, G. C. et al. 1987. The influence of an Acacia karroo tree on grass production in its vicinity. - J. Grassland Soc. S. Afr. 4: 83-88.

Thompson, K. 1987. Seeds and seed banks. - New Phytol., suppl. 106: 23-34.

Tolsma, D. J. et al. 1987. Seasonal variation of nutrient concentrations in a semi-arid savanna ecosystem in Botswana. - J. Ecol. 75: 755-770.

Urbieta, I. R. et al. 2008. Soil water content and emergence time control seedling establishment in three co-occurring Mediterranean oak species. - Can. J. For. Res. 38: 2382-2393.

Valladares, F. and Niinemets, U. 2008. Shade tolerance, a key plant feature of complex nature and consequences. - Annu. Rev. Ecol. Evol. Syst. 39: 237-257.

Vetaas, O. R. 1992. Micro-site effects of trees and shrubs in dry savannas. - J. Veg. Sci. 3: 337-344.

Virginia, R. A. 1986. Soil development under legume tree canopies. - For. Ecol. Manage. 16: 69-79.

Walker, B. H. et al. 1981. Stability of semi-arid savanna grazing systems. - J. Ecol. 69: 473-498.

Walker, B. H. and Noy-Meir, I. 1982. Aspects of the stability and resilience of savanna ecosystems. - In: Huntley, B. J. and Walker, B. H. (eds), Ecology of tropical savannas. Ecological studies 42. Springer, pp. 556-590.

Walter, H. 1971. Ecology of tropical and subtropical vegetation. - Oliver and Boyd.

Weltzin, J. F. and Coughenour, M. B. 1990. Savanna tree influence on understory vegetation and soil nutrients in northwestern Kenya. - J. Veg. Sci. 1: 325-334.

Whitford, W. G. et al. 1997. Stemflow contribution to the 'fertile island' effect in creosote bush Larrea tridentata. - J. Arid Environ. 35: 451-457.

Willis, K. J. and Whittaker, R. J. 2002. Species diversity - scale matters. - Science 295: 1245-1248. 